УДК 69.059.7:725.4 (477.53)

\title{
ОСНОВНІ ПРИНЦИПИ ТА ПРИЙОМИ РЕКОНСТРУКЦІЇ ПРОМИСЛОВИХ ОБ'ЄКТІВ ПІД БУДІВЛІ ГРОМАДСЬКОГО ПРИЗНАЧЕННЯ
}

Д-р техн. наук О.В. Семко, асп. Є.П. Воскобійник

\section{ОСНОВНЫЕ ПРИНЦИПЫ И ПРИЕМЫ РЕКОНСТРУКЦИИ ПРОМЫШЛЕННЫХ ОБЪЕКТОВ ПОД ЗДАНИЯ ГРАЖДАНСКОГО НАЗНАЧЕНИЯ}

Д-р техн. наук А.В. Семко, асп. Е.П. Воскобойник

\section{THE BASIC PRINCIPLES AND METHODS OF RECONSTRUCTION OF INDUSTRIAL BUILDINGS FOR USE AS PUBLIC FUNCTION}

Doct. of techn. sciences O.V. Semko, graduate student E.P. Voskobiynyk

У статті розглянуто основні принципи та прийоми реконструкції промислових об'єктів на основі їх реновації. Виділено головні чинники, щзо зумовлюють можливість і технічну та економічну доцільність такого способу реконструкиї промислової забудови. Запропоновано класифікацію основних факторів, щзо аналізуються під час проектування реконструкції на основі реноваціі промислової будівлі в громадську, а також їх експертну оцінку.

Ключові слова: промислові об'єкти, реконструкція, перепрофілювання, реновачія, громадські будівлі, торговельно-офісні комплекси.

В статье рассмотрены основные принципы и приемы реконструкции промышленных объектов на основе их реновации. Выделены главные факторы, обусловливающие возможность, техническую и экономическую иелесообразность такого способа реконструкиии промышленной застройки. Предложена классификаџия основных факторов, анализируемых при проектировании реконструкиии на основе реновации промышленного здания в гражданское, а также их экспертные оценки.

Ключевые слова: промышленные объекты, реконструкиия, перепрофилирование, реновация, общественные здания, торгово-офисные комплексы.

The article developments the basic principles and methods of industrial buildings reconstructions based on their renovations. The analysis of main factors that determine of possibility, technical and economical advisability of these reconstruction methods of industrial structures were consider. The classification of main factors with should be analyze in the design of renovation reconstructions of an industrial building for use as public function and these expert opinions were done.

Keywords: industrial objects, reconstruction, reshape, building renovations, public buildings, mall and office complexes.

Вступ. На початку XXI ст., на відміну від концепцій містобудування минулого сторіччя, реконструкція стає однією з найважливіших і найперспективніших тенденцій світового будівництва, адже сучасна концепція забудови міст вимагає якомога ефективнішого використання його територіі. Одним із напрямів удосконалення структури сучасного міста $€$ зміна функціонального призначення його територіального зонування [15-18]. Тому останнім часом особливу увагу містобудівники звертають на промислові території, що зазвичай внаслідок існуючої на сьогодні в нашій країні загальної тенденції зношення основних фондів підприємств, збудованих у 60-70 роки XX ст.у період масового будівництва, на тлі наслідків загальної економічної кризи частково або взагалі не використовуються. Таким чином, у 
структурі сучасного міста, що розвивається, в останні роки проблема реконструкції промислової забудови $є$ особливо актуальною.

Постановка проблеми у загальному вигляді та її зв'язок 3 важливими науковими чи практичними завданнями. При аналізі даної проблеми слід зауважити, що, за статистичними даними, у середньому відсоткова частка промислових зон у структурі сучасних міст складає від 10 до $50 \%$ (рис. 1,a) [13].

Проте докорінні зміни в галузі виробництва i економіки, що відбулися 3 поступовим переходом суспільства 3 індустріальної до постіндустріальної епохи, призвели до кризового стану або припинення діяльності багатьох заводів. Часто розташовані на цінних центральних територіях міста (рис. 1, б), ці об'єкти простоюють, ускладнюючи функціонування основних зон міста i створюючи екологічний та естетичний дисбаланс. Натомість існує дефіцит міської території для розвитку дрібного нешкідливого та наукомісткого виробництва, малого та середнього бізнесу, сфери обслуговування, особливо на ділянках, що розташовані біля головних міських магістралей i районів активного житлового будівництва. Актуальність реконструкції територій та основних фондів промислових підприємств, розташованих у центральній частині міста, підтверджується тим, що сьогодні для визначення цього поняття існує декілька поширених у літературі термінів, серед яких «реновація» та «редевелопмент» [10, 13]. Загалом само поняття «редевелопмент» має американське походження, вперше було застосовано в США, коли на початку 60 -х років $\mathrm{XX}$ ст., зважаючи на загальну економічну ситуацію, у країні з'явилися компанії, що скуповували дрібні застарілі підприємства, демонтували забудову та зводили на їх місці нові сучасні економічно привабливі об'єкти нерухомості. Натомість «реновація» передбачає адаптивне використання існуючих будівель, споруд, комплексів шляхом зміни їх функціонального призначення, тобто реконструкції $[10,14]$.

Разом 3 тим аналіз останніх джерел досліджень і публікацій $[5,7,8]$ свідчить, що формування торговельно-офісних центрів на основі реновації промислових будівель у цих роботах комплексно практично не розглядались. Проте, зважаючи на існуючий вітчизняний i закордонний досвід реновації промислових об'єктів і їхньої містобудівної ролі [5-9], на сьогодні має місце широке розповсюдження цього процесу на різних структурних рівнях промислових зон: реновація промислового району; промислового вузла; промислового майданчика; групи промислових будівель; окремої промислової будівлі.

Так, за статистичними даними досліджень [19], відсоткове співвідношення між новим будівництвом i реновацією в розвинутих країнах Європейського союзу, зокрема Фінляндії, за останні 30 від зросло від $(75 / 25) \%$ до $(55 / 45) \%$. Загалом, починаючи 3 2010 p., у Західній Європі інвестиції в реновацію існуючих об'єктів у середньому становлять близько 550 млрд євро в рік, перевищуючи майже в 1,5 разу обсяги нового будівництва.

Привабливість інвестицій у реновацію промислової забудови підтверджують i дослідження «Commecial RealEstate». Зокрема вартість типового будівництва офісу класу «В» в стадії «shell \& core» (без оздоблення), за даними роботи [13], становить близько 1000 дол. за $1 \mathrm{~m}^{2}$. Натомість його аналог, створений на основі реновації існуючого промислового об'єкта, у середньому буде коштувати на 20-50 \% дешевше, тобто 500800 дол. за $1 \mathrm{~m}^{2}$.

Проте однією 3 основних проблем, що постають перед інвесторами та забудовниками, $\epsilon$ відсутність на сьогодні науково обгрунтованої методики визначення можливості та технічної й економічної доцільності вибору того чи іншого методу подальшого використання існуючої забудови, що $\epsilon$ невирішеною раніше частиною загальної проблеми, якій присвячується стаття.

Зважаючи на це основною метою даних досліджень $\epsilon$ аналіз та узагальнення існуючого досвіду, формулювання основних передумов, принципів і прийомів реконструкції існуючої промислових об'єктів на основі їх реновації.

Основна частина дослідження. Аналіз досвіду реновації промислових об'сктів на прикладі м. Полтава. Створення громадських будівель на основі реновації промислових об'єктів дає можливість ефективного використання існуючої індустріальної забудови 3 одночасним вирішенням назрілих проблем 
розвитку міста. Особливо це є актуальним для нефункціонуючих промислових об’єктів, які розташовані в зоні впливу важливих міських магістралей і пересадочних вузлів у структурі сучасного міста, що розвивається (рис. 1, б).

При цьому слід розрізняти часткову (що відбувається у складі діючих підприємств при виведенні з експлуатації окремих цехів, які не відповідають вимогам сучасних технологій, 3 наданням їм громадської функції i може здійснюватися разом із реконструкцією i модернізацією підприємства) і комплексну (що передбачає повне припинення виробництва на території об'єкта 3 можливим винесенням його на іншу ділянку i заходи, спрямовані на забезпечення його нового функціонування в якості громадського об'єкта) реновацію.

Як приклад, аналіз сучасної забудови м. Полтава свідчить, що на головних композиційних осях міста розташовані промислові об'єкти, що на сьогодні фактично виведені з експлуатації (рис. 2, a, б). Ці об'єкти займають значні площі, мають неприглядний вигляд і негативно впливають на архітектурний облік міста. 3 іншого боку, на сьогодні в місті існує досвід доволі вдалої реновації промислових об'єктів (рис. 2, в, г).

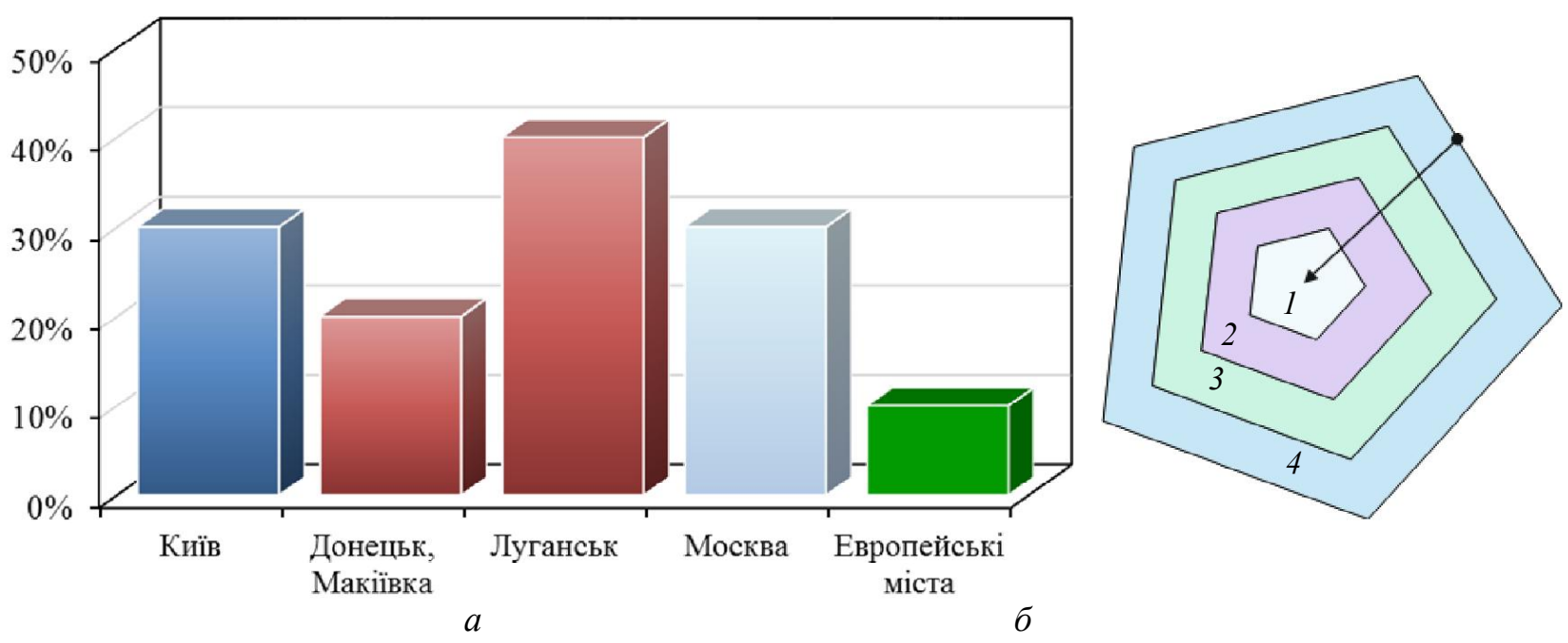

Рис. 1. Аналіз типової забудови міст:

$a$ - відсоткова частка промислових зон у структурі сучасних міст;

$\sigma$ - схема типової забудови міста; 1 - історичний центр; 2 - старі промислові підприємства; 3 - «спальні» райони; 4 - нові промислові підприємства

Зокрема реновація частини території турбомеханічного заводу вздовж вулиці Зінківської в м. Полтава (рис. 2, 2) є характерним прикладом застосування основних іiі прийомів. Розташування цього промислового об'єкта в центрі міста (вздовж червоної лінії забудови вулиці Зіньківської) та існуюча розвинута інфраструктура: наявність під’їздів і території для розміщення автостоянок, а також близькість до залізничного вокзалу зумовили вибір нового призначення розглядуваного об'єкта. Слід зазначити, що при цьому було застосовано декілька типових прийомів:
- повний демонтаж головного корпусу заводу зі зведенням на його місці торговельнорозважального комплексу «Київ»;

- перепрофілювання адміністративного корпусу заводу під будівлю громадського призначення 3 розміщенням торговельноофісних приміщень;

- реконструкція механічного корпусу заводу під будівлю громадського призначення 3 розміщенням торговельних приміщень продовольчого ринку та приміського вокзалу.

Реновація будівель турбомеханічного заводу $\epsilon$ яскравим прикладом часткової реновації, що відбувається у складі діючих 


\section{Будівельні матеріали, конструкції та споруди}

підприємств при виведенні 3 експлуатації окремих цехів, які не відповідають вимогам сучасних технологій, з наданням їм громадської функції.

3 іншого боку, під час реновації існує й сумний досвід із цілим рядом типових помилок.
Так, наприклад, при реконструкції одного 3 промислових промислового цехів через некваліфіковане оцінювання технічного стану конструкцій відбулось аварійне обвалення декількох залізобетонних плит покриттів.

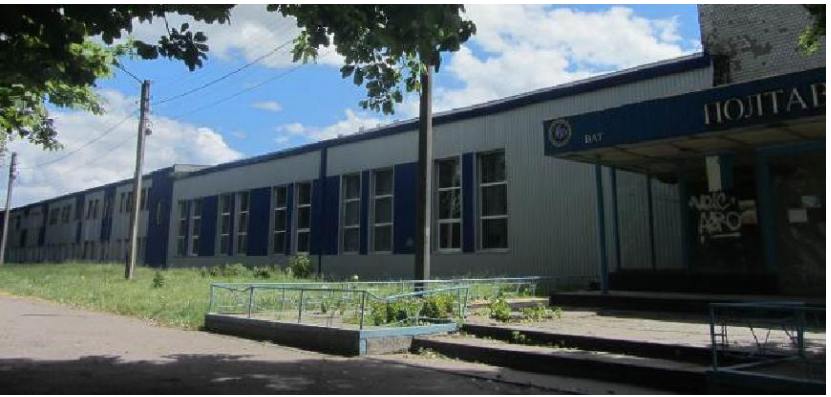

$a$



$\sigma$

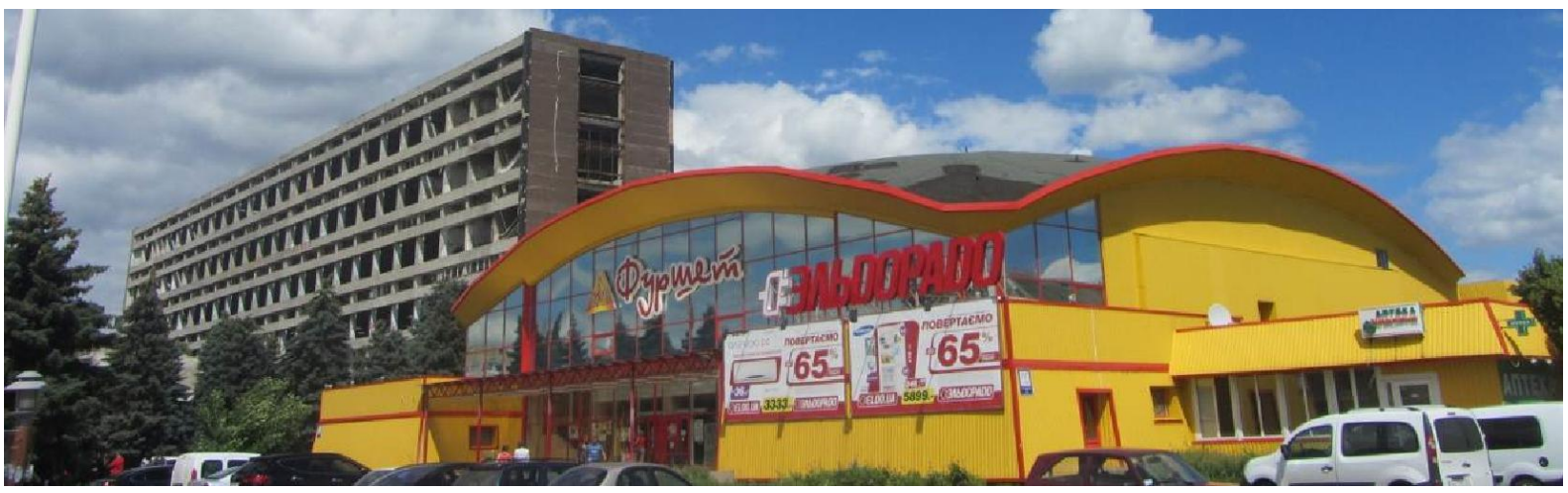

$B$

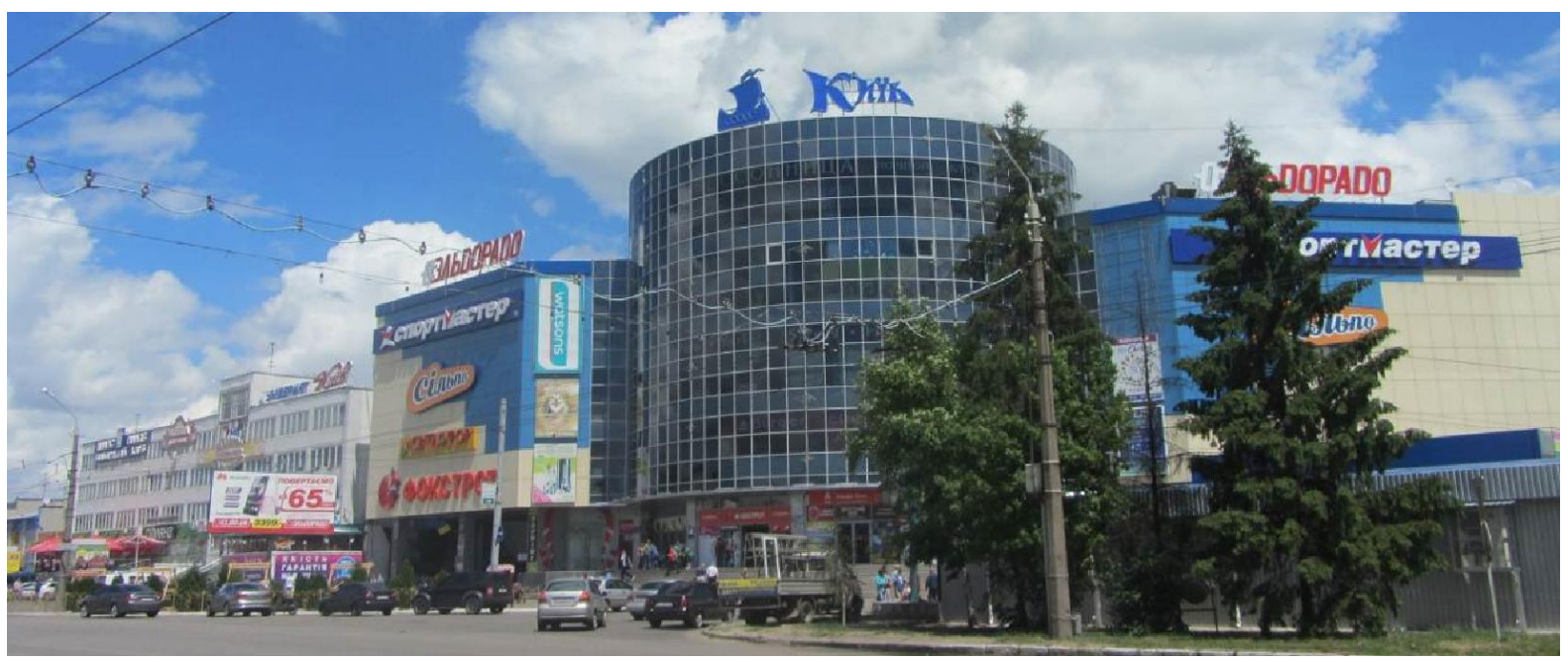

2

Рис. 2. Приклади нефункціонуючих промислових об'єктів м. Полтави та їх реновації: $a$ - загальний вигляд нефункціонуючої будівлі заводу «Полтавафарфор» по вулиці Маршала Бірюзова, $37 ; \sigma$ - загальний вигляд нефункціонуючої будівлі головного корпусу заводу «Знамя» по вул. Фрунзе в м. Полтава; в - реновація будівлі їдальні заводу «Знамя» на перетині вулиць Фрунзе та Київське Шосе; г - реновація території турбомеханічного заводу по вулиці Зінківській в м. Полтава 
Таким чином, розроблення проекту реновації промислового об'єкта потребує застосування комплексного підходу, що вже на стадії розроблення передпроектних рішень грунтується на всебічному аналізі всіх факторів, які зумовлюють можливість i доцільність такого виду робіт.

Аналіз факторів, що впливають на функціонально-планувальну та об'ємнопросторову структуру об'сктів реновації. Як відомо [3], на визначення типу громадської будівлі в умовах нового будівництва впливають такі фактори, як розташування в структурі міста (на периферії, у серединних або центральних районах (рис. $1, a)$ ); соціальнодемографічна характеристика району; розміщення ділянки будівництва відносно транспортних магістралей, пересадочних вузлів і пішохідних підходів. В умовах реновації до вищезазначених факторів додаються характеристики об'ємно-планувальної структури та історико-культурної цінності об'єкта, який перебудовується. Відповідно до розміщення в структурі міста i класифікаційних ознак промислових об'єктів можливо виділити відповідні типи торговельно-офісних комплексів, що виникають на основі реновації: спеціалізовані загальноміські; місцеві і регіональні; місцеві і міські торговельно-офісні комплекси.

Врахування цих факторів передбачає послідовне комплексне поетапне вирішення таких завдань:

-вибір нефункціонуючого промислового об'єкта реновації з одночасним визначенням типу та функціонального наповнення торговельно-офісного центру, який буде створено за допомогою графоаналітичного методу та методу експертних оцінок;

-вибір принципів і прийомів об'ємнопланувальної перебудови на основі визначення історико-культурної цінності об'єкта (або його частин), аналізу його планувальної структури 3 точки зору можливостей розміщення нових функцій та одночасним коригуванням типу, формату і функціональної моделі торговельноофісного комплексу;

- розроблення варіантів архітектурнопланувальних рішень торговельно-офісного комплексу; -оцінювання розроблених варіантів i
вибір оптимального рішення на основі показників i критеріїв економічності та ефективності.

Основними вирішальними факторами при перепрофілюванні промислових будівель у громадські, зокрема торговельно-офісні комплекси $є$ дотримання нормативних вимог щодо трьох груп основних факторів: містобудівні, об'ємно-планувальні та конструктивні.

Основні принципи, методи та прийоми реновації промислових об'єктів під будівлі громадського призначення. Зважаючи на проведений вище аналіз, до основних принципів реновації промислових об'єктів під будівлі громадського призначення слід віднести:

- принцип містобудівної відповідності;

- принцип функціональної відповідності; відності;

-принцип об'ємно-планувальної відпо-

- принцип економічної ефективності.

Внаслідок цього розміщення торговельних функцій у перебудованих промислових об'єктах можливе шляхом:

- розміщення функцій, які відповідають конструктивно-планувальним характеристикам існуючої будівлі;

- розміщення функцій, що не відповідають властивостям існуючої будівлі, разом із вживанням додаткових архітектурнопланувальних заходів.

Таким чином, обрані методи об'ємнопланувальної перебудови промислових будівель залежать від об'ємно-планувальних і історико-культурних характеристик існуючих об'єктів, а також від можливості виконання містобудівних i функціональних вимог до громадських будівель в умовах реновації.

I-метод максимального збереження існуючої структури промислової будівлі: застосовується за умов іiі значної історикокультурної цінності та/або відповідності планувальних характеристик вимогам до організації торговельного закладу, неможливості просторового розвитку об'єкта. Це відбувається при використанні умовної моделі торговельно-офісного комплексу в існуючій об'ємно-планувальній структурі при повному іiї збереженні.

II - метод максимального збереження зовнішньої оболонки разом зі зміною об'ємно-планувальної структури промислової будівлі: застосовується за умов її значної та середньої історико-культурної цінності, при 
цьому зміни відбуваються в межах зовнішнього огородження. Виконання вимог до функціонально-просторової організації торговельно-офісного комплексу досягається за рахунок виявлених об'ємно-планувальних прийомів реновації:

-повне об'єднання простору за рахунок звільнення від внутрішніх стін, перегородок, колон і міжповерхових перекриттів;

-часткове об'єднання простору за рахунок створення атріумів і багаторівневих інформаційно-комунікаційних просторів;

- розподіл існуючого простору шляхом зведення додаткових поверхів, галерей, антресолей;

- включення самостійної конструктивнопланувальної системи;

-перепланування зі встановленням стаціонарних та трансформованих елементів;

-організація простору за допомогою встановлення об'ємних блоків; розмежування простору за допомогою встановлення обладнання.

\begin{tabular}{lcr}
\multicolumn{1}{c}{ III } & метод максимальної зміни \\
iснуючої & планувальної & структури i \\
зовнішньої & оболонки: & зумовлено
\end{tabular}
невідповідністю вимог торговельно-офісних функцій вихідним характеристикам форми, незначною історико-культурною цінністю промислового об'єкта. У такому випадку виконання вимог досягається за допомогою прийому зміни габаритів будівлі:

-винесення окремих функцій у

надбудову;

-винесення окремих функцій у

прибудову;

-нове будівництво в комплексі;

- перекриття подвір'їв;

- будівництво вставок між корпусами;

-об'єднання декількох будівель під загальним мега-простором.

Отже, обгрунтування можливості та доцільності використання такого підходу до реконструкції, а саме реновації існуючої промислової забудови зі зміною їх призначення, слугує підгрунтям для подальшого розроблення відповідних проектних рішень. Адже відповідно до чинних нормативних документів [1-4], на відміну від об'єктів промисловості, до будівель громадського призначення існують певні специфічні

архітектурно-планувальні, санітарні, пожежні та інші вимоги. При прийнятті рішення щодо доцільності того чи іншого методу реконструкції всі ці фактори повинні бути детально проаналізовані.

Основними вирішальними факторами при перепрофілюванні промислових будівель у громадські є дотримання нормативних вимог щодо трьох груп основних факторів, наведених на рис. 3.

При цьому основним містобудівним фактором (рис. 3, поз. 1) є розміщення та параметри ділянки експлуатації будівлі, що підлягає реконструкції (перепрофілюванню), яка повинна відповідати вимогам забезпечення нормативної інсоляції приміщень громадської будівлі, можливості влаштування (або наявності) зручних підходів, під'їздів і автостоянок, організації благоустрою 3 належним рівнем (\%) озеленення. Розміщення громадських будинків і споруд на земельних ділянках повинно відповідати містобудівним, екологічним, протипожежним, санітарним нормам. При невідповідності ділянки експлуатації існуючої промислової будівлі цим вимогам іiї перепрофілювання неможливе.

До основних об'ємно-планувальних вимог (рис. 3, поз. 2) щодо громадських будівель $\epsilon$ наявність (або конструктивна можливість додаткового влаштування) основних входів, що повинні мати зручні підходи та оптимальні розміри, враховуючи фізичні можливості всіх розрахункових категорій відвідувачів. Кількість входів (виходів) повинна відповідати розрахунку виходячи з пропускної спроможності будівлі, а також експлуатаційних вимог.

Окрім того, необхідно дослідити можливість улаштування ліфтів, висоту приміщень i ступінь вогнестійкості тощо. Порівняльний аналіз об’ємно-планувальних факторів (рис. 3, поз. 2) свідчить, що при недотриманні вимог стосовно висоти поверху існуючої промислової будівлі щодо відповідних вимог, які висуваються до громадських об'єктів, iï подальша реконструкція (зі зміною призначення) практично неможлива або зумовлює виконання часткового демонтажу існуючих конструкцій, що потребує значних капіталовкладень. 


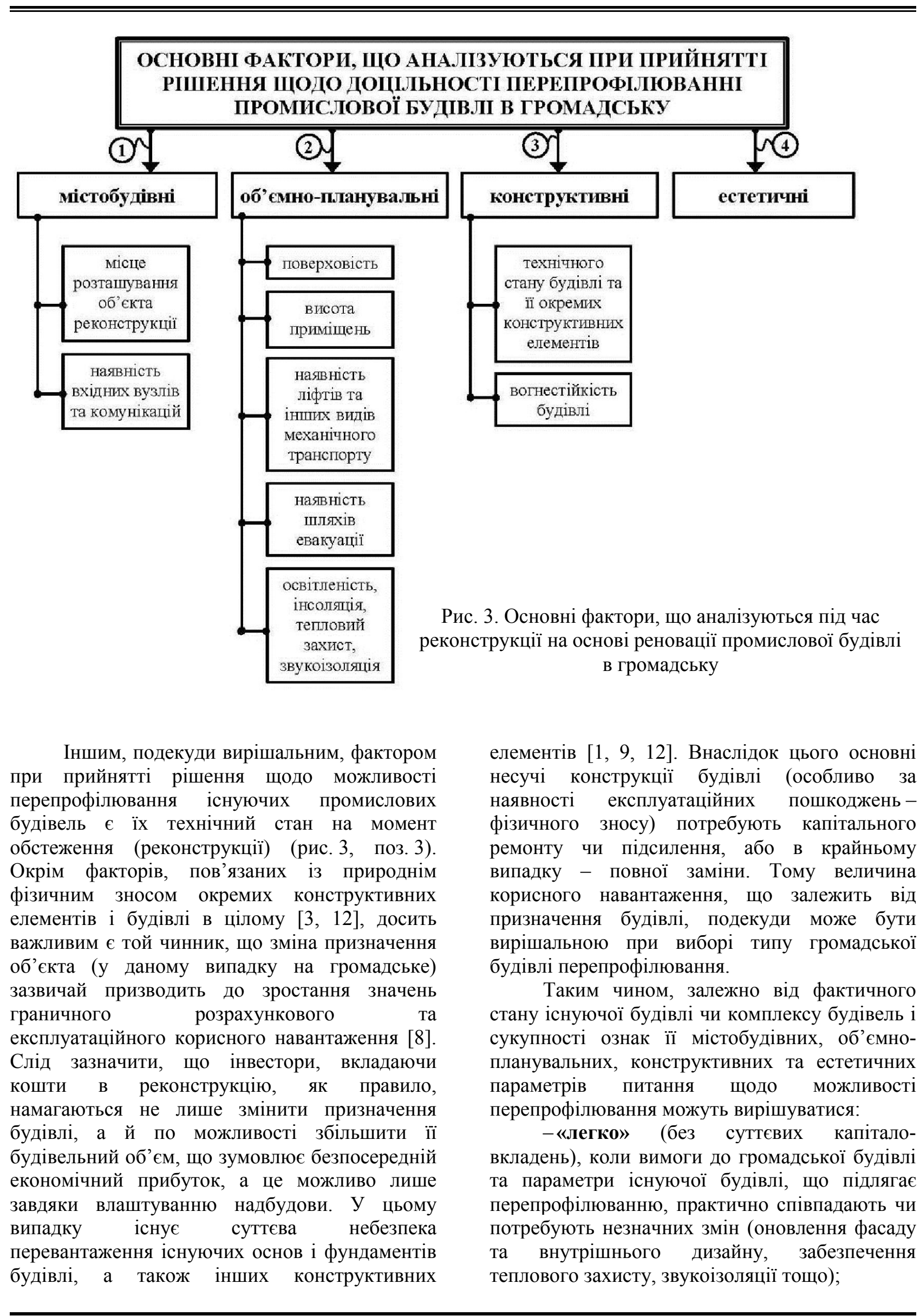


-«3 незначними затратами» (влаштування додаткових евакуаційних виходів, у тому числі зовнішніх ескалаторів, капітального ремонту існуючих несучих конструкцій, перепланування приміщень);

-«зі значними затратами», коли, крім вище перерахованих факторів, існує необхідність у підсиленні чи заміні окремих конструктивних елементів існуючої будівлі (постає питання доцільності та економічного обгрунтування перепрофілювання);

- «взагалі недоцільне», коли забезпечення нормативних вимог, що ставляться до громадських будівель, неможливе.
Висновки. Формування торговельних комплексів в умовах реновації промислових будівель грунтується на оптимальному поєднанні принципів збереження та гнучкої модифікації об'ємно-планувальних, архітектурно-художніх i конструктивних характеристик існуючої забудови. Принципи та прийоми формування торговельних комплексів на основі реновації допомагають вирішити проблеми розвитку планувальної структури міста, надають широкий спектр варіантів архітектурно-планувальних рішень, позбавляють від необхідності знесення існуючих промислових об'єктів.

\section{Список використаних дюерел}

1. Воскобійник, О. П. Комплексні методи керування ризиками під час експлуатації будівель та споруд [Текст] / О. П. Воскобійник // Металеві конструкції. - 2013. - Т. 19. - №3. - С. 183-189.

2. Восстановление и усиление строительных конструкций аварийных и реконструируемых зданий [Текст]: атлас схем и чертежей / А.И. Мальганов, В.С. Плевков, А.И. Полищук. - Томск : Том. ун-т, 1990. - $456 \mathrm{c}$.

3. ДБН В.2.2-9-2009. Громадські будинки та споруди [Текст]. - Чинний 3 2010-07-01. - К.: Мінрегіонбуд України, 2009. - 49 с.

4. ДБН В.2.2-17-2006. Доступність будинків і споруд для маломобільних груп населення [Текст]. - Чинний з 2007-05-01. - К. : Мінрегіонбуд України, 2006. - 20 с.

5. ДБН В. 1.2-7-2008. Основні вимоги до будівель і споруд пожежна безпека [Текст]. - Чинний з 2008-10-01. - К.: Держбуд України, 2008. - 28 с.

6. ДБН В.2.5-28-2006. Природне і штучне освітлення [Текст]. - Чинний 3 2006-10-01. К.: Мінрегіонбуд України, 2006. - 62 с.

7. ДБН В.1.2-2:2006. Система забезпечення надійності та безпеки будівельних об’єктів. Навантаження і впливи [Текст]. - Чинний з 2007-01-01. - К.: Мінбуд України, 2006. - 59 с.

8. Мельчаков, А.П. Расчет и оценка риска аварии и безопасного ресурса строительных объектов (Теория, методики и инженерные приложения) [Текст]: учеб. пособие / А.П. Мельчаков. - Челябинск: Изд-во ЮУрГУ, 2006.- 49 с.

9. Новая жизнь заброшенных построек [Електронний ресурс] // Електронний портал Zabort.ru. Режим доступа: http:// zabort.ru/blog/poznavatelno/ 25705.html.

10. Реконструкция зданий и сооружений [Текст]: учеб. пособие / А.Л. Шагин, Ю.В. Бондаренко, Д.Ф. Гончаренко, В.Б. Гончаров; под ред. А.Л. Шагина. - М.: Высшая школа, 1991. - 352 с.

11. Семко, О.В. Керування ризиками при проектуванні та експлуатації сталезалізобетонних конструкцій [Текст]: монографія / О.В. Семко, О.П. Воскобійник. - Полтава: ПолтНТУ, 2012. - 514 с.

12. Сносить нельзя, перепрофилировать [Електронний ресурс] // Електронний портал Redeveloper.ru. - Режим доступа: http:// www.redeveloper.ru/ru/np1.html.

13. Супрунович, Ю.О. Реновація як засіб відродження нефункціонуючих промислових підприємств міста в новій якості [Текст] / Ю.О. Супрунович, Н.Ю. Житкова // Сучасні проблеми архітектури та містобудування. - К.: КНУБА, 2005. - Вип. 14. - С. 15-28.

14. Шепелев, Н.П. Реконструкция городской застройки [Текст]: учеб. издание / Н.П. Шепелев, М.С. Шумилов. - М.: Высшая школа, 2000. - 269 с.

15. Koebel, C. Urban Redevelopment, Displacement and the Future of the American City [Text] / C. Theodore Koebel. - Community Affairs Office Federal Reserve Bank of Richmond, 1996. - 32 p.

16. Rogis, T. Converted Industrial Buildings: Where Past and Present Live in Formal Unity [Text] / T. Rogis. $-2009 .-159$ p. 
17. Rosen, M \& Sullivan, W. From Urban Renewal and Displacement to Economic Inclusion: San Francisco Affordable Housing Policy 1978-2012 [Text] / M. Rosen \& W. Sullivan. - 2012. - 60 p.

18. Vainio, T. Building renovation - a new industry? [Text] / T. Vainio // Management and Innovation for a Sustainable Built Environment. 20 - 23 June 2011, Amsterdam, The Netherlands.

Семко Олександр Володимирович, доктор технічних наук, професор, кафедра архітектури та міського будівництва, Полтавський національний технічний університет імені Юрія Кондратюка. Е-mail: a.semko@mail.ru.

Воскобійник Свгеній Павлович, аспірант, кафедра архітектури та міського будівництва, Полтавський національний технічний університет імені Юрія Кондратюка. E-mail: cgvosko@gmail.com.

Semko Alexander Vladimirovich Dr. of Sc., Prof., Civil Engineering faculty, Department of Architecture and Urban Engineering, Poltava National Technical Yuri Kondratyuk University, e-mail: a.semko@mail.ru.

Voskobiynyk Yevheniy Pavlovich, graduate student, Civil Engineering faculty, Department of Architecture and Urban Engineering, Poltava National Technical Yuri Kondratyuk University, e-mail: cgvosko@gmail.com.

Стаття прийнята 01.09.2015 p. 